\title{
Total Quality Management and SMPS Performance Effects in Nigeria: A Review of Six Sigma Methodology
}

\author{
Kenneth Enoch Okpala \\ Department of Financial Studies (Accounting), Redeemer's University \\ Mowe, Ogun Sate. Nigeria \\ Tel: 805-507-1683_E-mail: kenokpala@aol.com; kenenoch@yahoo.ca
}

\author{
Received: Nov. 8, 2012 Accepted: December 10, $2012 \quad$ Published: December 13, 2012 \\ doi:10.5296/ajfa.v4i2.2641 URL: http://dx.doi.org/10.5296/ajfa.v4i2.2641
}

\begin{abstract}
Though small and medium practices (SMPs) which constituted over $70 \%$ of auditing firms in Nigeria have been in existence from the inception of accountancy profession but have not been given the required attention. This research paper is exploratory on the ground that SMPs is a new concept. The study investigated the effect of total quality management (TQM) on the performance of the subsector through the use of Six Sigma Methodology (SSM) to improve current business system. The population of the study consists of 884 SMPs in Nigeria. 133 respondents were purposively selected representing a sample fraction of $15 \%$. Questionnaire was administered at random and opinions elicited and analyzed. Pearson Product Moment Correlation Method was used to confirm the hypotheses of the study. Finding obtained revealed that leadership style, management of people and consumers focus are the strongest significant predictors of TQM and operational performance but are lacking in most in SMPs operations. It also discovered that TQM programmes when implemented will influence the quality of auditing services that meets clients' expectations within the ambit of standards and regulations. The study therefore recommends that SMP should embrace SSM to have significant clients' relationship, improved performance and maximize institutional prosperity.
\end{abstract}

Key words: Total Quality Management, SMP, Performance, Six Sigma Methodology, Nigeria 


\section{Introduction}

The concept of TQM was originally developed by Edwards W. Deming, after World War II for improving the production quality of goods and services. The idea was adopted by Japanese in 1950 that employed it to improve their postwar business and dominated world markets by the 1980s (Evans \& Dean, 2003). Manufacturers in United States then realized that the existing nineteenth century assembly line factory model in use was obsolete and needed to be changed if Americans must compete in modern global markets and be in the forefront among nations of economic consequence (Evans \& Dean, 2003). This move motivated western companies to commence their own quality initiatives which led to a new phase of continuous quality improvement known as TQM between 1980s and 1990s. Initially, the idea of quality was based on reducing defects and errors in products and services through the use of measurements and the outcome was the achievement of superior performance and minimized costs of production. Organizations realized that achievement of enduring improvement may be impossible without significant attention to the quality of the management practices excised on the day to day basis, caliber of staff in employment and relationship between service provider and the clients (Nwabueze, 2001). This made TQM all encompassing (Demirbag, et al 2006). Schonberger \& Knod (1997) managers noticed that the approaches they use to listen to customers and develop relationships, craft out strategy, measure performance, analyze data, train employees, deliver products and services and provide leadership in their organizations are the true enablers of quality, satisfaction, and business success.

Empirical evidence shows that in Nigeria, TQM was mainly practiced by multinationals that understood the concept but was notably implemented locally with success by Jim Ovia - CEO of Zenith International Bank Plc. The Bank's management of quality was overhauled; first class graduates were employed, inducted and maintained with a clear cut reproductive management strategy and succession plan. Every department understood how to relate quality to their roles to achieve the selected strategies. All staff sees the organization as a single entity for the purpose of providing value to consumers. TQM implementation eliminated long service queue through prompt service, quality service were rendered and bank customers were satisfied. All these led to efficient operations, cost reduction and high profit maximization which elevated the bank to Nigeria's top five, few years after its establishment (Zenith Economic Quarterly, various issues). Most SMPs in Nigeria does not pay attention to quality of service renders to clients. The poor quality services ranges from the reckless audited financial report to members of his client company, to tax accounts prepared and presented to the tax authorities without due regards to accounting and auditing standards and other regulatory framework upon which such service provisions are based. The service delivery handicap of SMPs emanates from inadequate input resources such as finance, professional manpower, specialized skills and modern technology (IFAC, 2010). Surya., Pal-Pandi, \& Jeyathilagar, (2007) noted that inability to implement TQM has brought many problems to SMPs as follows (i) Failure to improve services to satisfy clients (ii) Failure to initiate training-on-the job to achieving quality (iii) Failure to adopt and institute leadership in all levels of management aimed at the supervision of audit staff and independent review of audit working papers to improve performance and (iv) Failure to embrace continuous improvement in all aspects of 
services input to gain business growth. The main objective of this study is to investigate TQM and SMPs performance effects in Nigeria. The study will also examine the meaning of quality and application of Six Sigma Methodology to SMPs service delivery. The research questions on which attempt is made to provide solution includes (i) how does TQM effect the performance of SMPs in Nigeria? And (ii) To what extent has SSM application influenced SMPs services delivery in Nigeria? The Research Hypotheses include: (i) There is no significant relationship between TQM and SMPs performance in Nigeria and (ii) Six Sigma Methodology has no significant influence on SMP services in Nigeria.

\section{Review of Related Literature}

Quality management has been widely practiced both locally and internationally in different sectors and subsectors of different economies. The concept is linked to several international self-assessment models that evaluate the TQM efforts and in line with the International Organization for Standardization (ISO 9000:2000), which represents a system as a common denominator for what business quality entails internationally. Six Sigma is a logical and process improvement methodology that helps to achieve TQM (Snee, 2004). Bilich \& Neto (2000) stated that quality as a macro function of institutions must be present in the day-to-day administration such as establishment of policies, decision process, selection of personnel, allocation of resources, definition of priorities and service delivery to satisfy customers requirements. Quality management is not derived from a single idea or person and this may be the reason for divergence view and definitional problems experienced by managers during the implementation of the strategy. SMEs are worse off in the matter as they have poor understanding of TQM terminology (Oakland, 2000). Eriksson \& Hansson, (2003) stated that TQM brings together the constellation of productivity, ethical leadership and performance into a unique relationship. The question therefore is what is TQM? Yong \& Wilkinson (2001) noted that TQM strategies focus on quality improvement to achieve outcomes such as financial results, customer satisfaction, marketing results, operational results, community results and employee results. Hoyer \& Hoyer (2001) defines quality as two levels concept: level one consist of producing products or delivering services whose measurable characteristics satisfy a fixed set of specifications and Level two means products and services that satisfy customer expectations for consumption. Evans \& Dean (2003) stated that quality is much more than conformance to specifications. They identify eight attributes of quality as performance, features, reliability, conformance, durability, serviceability, aesthetics and perceived quality. 'Rouse, (2005) defined TQM as a comprehensive and structured approach to organizational management that seeks to improve the quality of products and services through ongoing refinements in response to continuous feedback. Nwabueze (2001) summaries TQM as having three major requirements outlined as follows: (i) Total: Participation of all staff in an institution-wide process. TQM requires continuing improvement and getting things right first time. This demands team work and maintenance of good relationships at all cedars (ii) Quality: Meeting customer requirements at least exactly. TQM requires customer-agreed specifications which allow the supplier to measure performance and customer satisfaction. Individuals and teams need to use quality tools and systems to facilitate measurement and problem solution (iii) 


\section{Macrothink}

Management: Enabling conditions for total quality. TQM requires leadership and total commitment from senior management to quality goals.

\subsection{Paradigm shift in quality management over time}

Total quality management has been called various names and this is in response to shift in the model development. It is known as continuous quality improvement (CQU); statistical quality control (SQC); total quality control (TQC), etc. Each of these ideas encompasses the underlying scheme of productivity initiatives that increase efficiency and profit by improving the product or services (Cua., McKone., \& Schroeder, 2001). Pycraft, Singh \& Phihlela (2000) stated that quality was initially achieved by inspection and screening out defects before customers noticed them. The quality control concept was developed as a more systematic approach not only to detect defects but also to solve quality problems. Assurance came with a wider responsibility for quality to include functions other than direct operations of an institution and makes increasing use of more sophisticated statistical quality techniques (Dale, 2003). The paradigm shift is illustrated by figure 1 below:

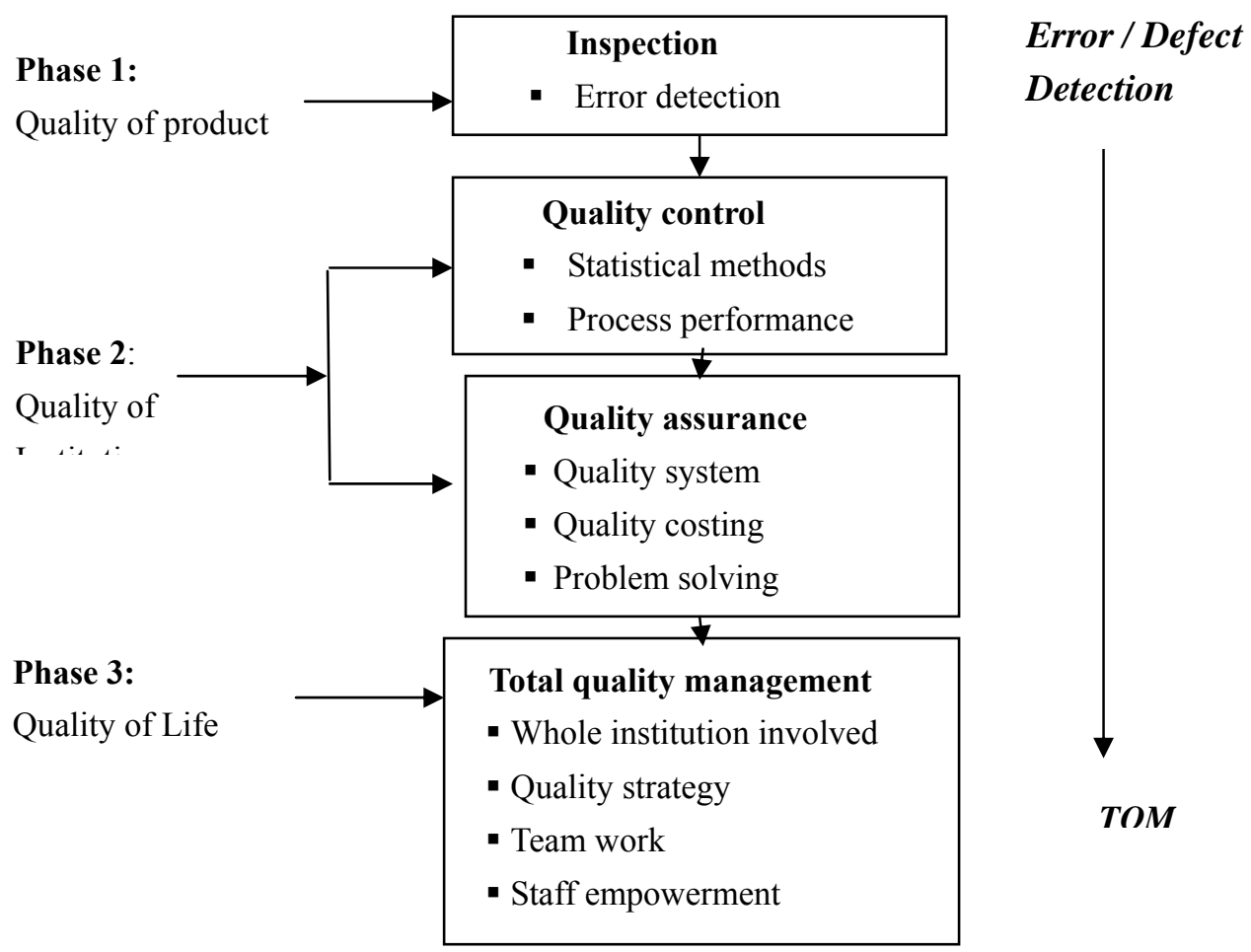

Figure 1. Paradigm shift through time

Source: Adapted from Dale (2003) and Pycraft, Singh \& Phihlela (2000)

Pycraft, et al (2000) stated that phase 3 involves meeting the clients' expectations, improving all parts of the institution, examining all costs relating to quality, developing systems and 
procedures to support quality improvement and developing a continuous process of improvement

\subsection{Dimensions of Service Quality}

A quality standard is that level of quality which defines the boundary between acceptable and unacceptable (Pycraft et al., 2000). Service standards should serve as indicators of performance to determine whether the service is meeting the customer's expectations or not (Evans \& Dean (2003). Service standards and feedback mechanism should be established in the entire organization to aid measurement and reporting (Hansson, (2003). Zeithaml and Bitner (1996) noted that understanding the dimensions will help SMPs both to appreciate clients' needs and also to provide acceptable standard of service. The five broad dimensions are shown in Table 1 below:

Table 1. Five Broad dimensions of service quality

\begin{tabular}{|l|l|l|}
\hline Dimension & Definitions & Application to SMPs service delivery \\
\hline Tangibility & $\begin{array}{l}\text { Appearance of physical facilities, } \\
\text { equipment, personnel and writing } \\
\text { materials }\end{array}$ & $\begin{array}{l}\text { This enables SMPs clients to make inferences about the service } \\
\text { quality based on the firm's tangibles such as office buildings } \\
\text { and layout, letterhead paper and staff outlook (Jamal \& Naser, } \\
\text { 2002). }\end{array}$ \\
\hline Reliability & $\begin{array}{l}\text { Ability to deliver all service promises } \\
\text { dependably and accurately. }\end{array}$ & $\begin{array}{l}\text { Reliability occurs when SMPs keeps every promise made to } \\
\text { the clients. It should under promise and over perform }\end{array}$ \\
\hline Responsive- & $\begin{array}{l}\text { Willingness to provide prompt } \\
\text { service and help clients. }\end{array}$ & $\begin{array}{l}\text { This helps SMPs to resolve client's problems as quick as } \\
\text { possible and avoid dissatisfaction. }\end{array}$ \\
\hline Assurance & $\begin{array}{l}\text { Employees' knowledge, courtesy and } \\
\text { ability to inspire trust and confidence }\end{array}$ & $\begin{array}{l}\text { This enables SMPs reports to be made without mistakes, } \\
\text { behaves pleasantly and politely and makes clients feels like a } \\
\text { king. }\end{array}$ \\
\hline Empathy & $\begin{array}{l}\text { Caring, easy access, good } \\
\text { communication, understanding and } \\
\text { individualized attention to customers. }\end{array}$ & $\begin{array}{l}\text { Empathy enables clients to deal with the SMP more easily } \\
\text { (Levesque \& McDougall, 1996). Communication enables } \\
\text { clients' complaint to be addressed through proper channels. }\end{array}$ \\
\hline
\end{tabular}

Source: Zeithaml et al. (1996)

Recently, quality management emphasizes the concept of zero defects (error-free work) and has become popular as management pursues the climate. All members of staff in the organization are encouraged to dedicate themselves to the idea in service rendition (Vroman \& Luchsinger 1994). Mani., Putterill., \& Sluti (1994) considers service to be a process that goes through various stages and in each stage, certain inputs are required from the service provider. If the quality of the service is inferior at any stage, it will result in the end product that will not meeting the clients' expectations. In audit service cycle, quality testing must be performed at each input point such proper plan, designing good audit program, good record keeping and extensive review of audit working papers as once delivered, the service cannot be recalled as in 
the case of a tangible product. Chang., Lin., Yang., \& Sheu, (2003).stated that each institution that renders services must have a service strategy which outlines focus point for all staff, departments and management to direct the entire efforts. The management should see quality from organizational point of view and each department/unit within the organization need to adopt the same strategy to serve the clients with excellent quality at lower cost, quicker response time with greater flexibility (Schonberger 1990). This will be made easy by adopting the above five broad dimensions of service quality.

\subsection{Small and Medium Practice (SMP) in Nigeria and Total Quality Management}

There is no clear acceptable definition of SMP as at now. The International Federation of Accountants (IFAC) defines such firm as an accounting practice (audit firm) whose clients are mostly SMEs, which depends on external sources to supplement limited in-house technical resources and hold a limited number of professional staff (IFAC 2010). Linking SMP to SMEs loaded the definition with difficulties and confusions as what constitutes an SME differs from one country to another. The definition of SMEs in existing literature varies although the primary concept remained the same. Ayagari \& Demirguc-kunt, (2003) contends that the definition of SME varies according to context, author and countries. In USA, Britain and Canada SME is defined in terms of annual turnover and the number of paid employees (Ekpeyong \& Nyang, 1992; Ariyo, 1999). In Nigeria, the Central Bank of Nigeria in its monetary policies circular No. 22 of 1988 described SMEs as those enterprises which has annual turnover not exceeding 500,000 naira. It means that the classification is subjective and based on different value judgment (Wiklund \& Wiklund, 2002).

According to IFAC (2010) the fundamental reason for defining SMP is to form a basis for the following: (i) to provide a distinction between the second tier and large accountancy organizations (ii) to provide snapshot of key challenges and trends influencing SMPs globally and SMPs opportunity to share their insights on key developments facing them and their small business clients (iii) to provide resources through services and products to SMP by umbrella international and regional organizations such as IFAC, Association of Accountancy Bodies in West Africa (ATWA) and Confederation of Asian and Pacific Accountants (CAPA) (iv) to enable appropriate members to assess the proportion of resource provided (v) to lobby on behalf of SMPs to government and regulatory bodies at national and international level and (vi) to provide an important advisory services to SMPs. IFAC Board established SMP Committee to represent the interests of professional accountants operating as SMPs. The committee investigates ways to respond to the needs of SMP as means for sustainable economic development. Currently, ICAN has membership of 32,722 professional (Okpala 2012) with 6,500 Chartered Accountants holding the Institute's practising licences (Okwuadigbo, 2012). Interestingly, about $72 \%$ of this number is made up of sole practitioners. Classifications of firms by ICAN are as follows. (i) Small Practices: 2-4 partners (ii) Medium practices: 5-9 partners and (iii) Large practices: 10 above. The total number of Audit firms in Nigeria as at 27th May, 2011 is 916 firms categorized by number of partners as shown in table 2 below: 
Table 2. Categories of Firms by Number of Partners

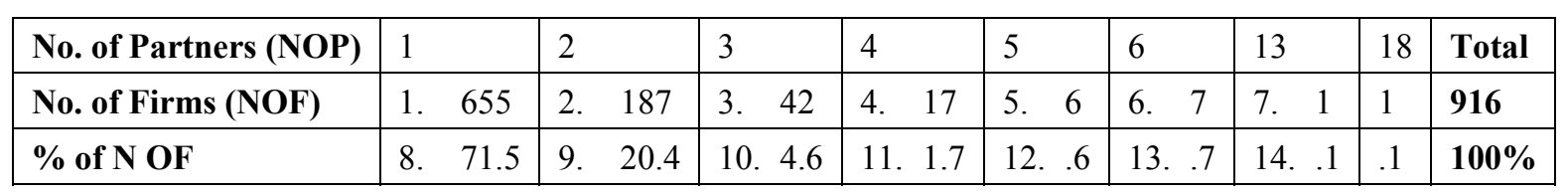

Source: Membership Affairs Record (May, 2011)

Evident from the table 2 above shows that sole practitioners comprise of the highest number of practising firms in Nigeria. The reasons for the dominance of this type of business association include: (a) Unwillingness of the sole practitioner to lose control (b) Inability to look beyond the immediate environment (c) Lack of collaboration among chartered accountants (d) Lack of specialization and (e) The desire to work independently and take all the profit. From the practice monitoring exercise survey, most sole practitioners and other small audit firms are faced with many operational challenges and as a result have adopted different survival tactics which impact negatively on the quality of services rendered to their clients (Okwuadigbo, 2012). The Institute is encouraging firms to merge and pool resources to ensure improved capacity and provides high quality services. Managing Partners of SMP should embrace TQM to Ensure that meet clients' expectation, produce services that conform to meet international standards, have excellent performances, attracts development, eliminate the existing high mortality rate of SMPs and adopt a comprehensive and structured approach to auditing practice management that improves the quality of services through ongoing refinements in response to continuous feedback from clients.

\subsection{Six Sigma Methodology and SMP Performance}

According to Wyper \& Harrison (2000) six sigma is a logical and methodical approach to achieving disciplined quality improvements in areas critical to the success of any service-oriented organization. It was originally developed by Motorola in 1986 and became well known after Jack Welch made it a central focus of his business strategy at General Electric in 1995. Today it is widely used in many sectors locally and internationally. TQM is made up of adding Six Sigma Methodology (SSM) to Current Business System (CBS). This can be expressed mathematically as: $\boldsymbol{C B S}+\boldsymbol{S S M}=\boldsymbol{T Q M}$. Six Sigma implementation assisted Motorola to win the 1988 Malcolm Baldrige National Quality Award and within the first five years achieved savings of \$US2.2 billion (Lucey 2002). Nave (2002) stated that six sigma methodology includes five steps commonly known as DMAIC as follows: define; measure; analyze; improve and control. These steps endeavour to adopt a smarter way of doing things so as to minimize the occurrence of errors. It emphasizes on doing things right the first time, rather than spending effort on correcting errors. According to Tennant (2001) SMP can apply SSM in the following ways: Step 1: Definition starts with conducting a baseline study to identify SMP market segments and their problems. Goals should be accurately defined and must follow the SMART principles: $\mathrm{S}=$ Specific; $\mathrm{M}=$ Measurable; $\mathrm{A}=$ Attainable; $\mathrm{R}=$ Relevant and $\mathrm{T}=$ Timely. Step 2: Improvement measurement parameters and extent to be improved should be properly established. Actual data should be collected to enable measurement and 
calculation of variances between the current and the desired performance. Step 3: Once the data are analyzed, it will provide insights into the process to be improved. These include identifying the fundamental causes of the defects or errors to enable improvement in the services delivery. Step 4: The improve phase is the fourth in SSM. Analysis in step 3 will trigger SMPs management action and the basis for improvements in processes capable of resolving client problems. Step 5: Control Phase: This phase is where improvements implemented are made manifest. It is the most neglected phases in the methodology. One of the main reasons for improvements not showing is because this phase is overlooked.

\subsection{Virtuous Circle of DMAIC}

Costin (1994) emphasized that quality is the most significant of all competitive weapons in the business arena and its implementation should be an ongoing process. It should be allowed to become a philosophy and culture of the whole institutions. Improving a service should be a continuous process and in audit firms, each employee should accept responsibility for that process (Wilkinson., Marchington., Goodman., \& Ackers, 1992) DMAIC in SMP operations should be on cyclical basis. The control phase (Step 5) will further provide an avenue for the redefinition stage (Step 1). A key philosophy in dealing with clients is that they are responsible for defining what quality is (Mohammed. \& Shamsuddoha, 2012) and for SMP to have a successful implementation of SSM, all stakeholders should be treated as business partners with all parties working together to deliver quality services (Schroeder, 2006).

\subsection{Benefit of Six Sigma methodology}

Chao-Ton, \& Chia-Jan, (2008) classified the benefit of SSM into hard saving involving tangible outcome in relation cost and revenue and soft savings involving actual improvements. This is shown in figure 2 below: 


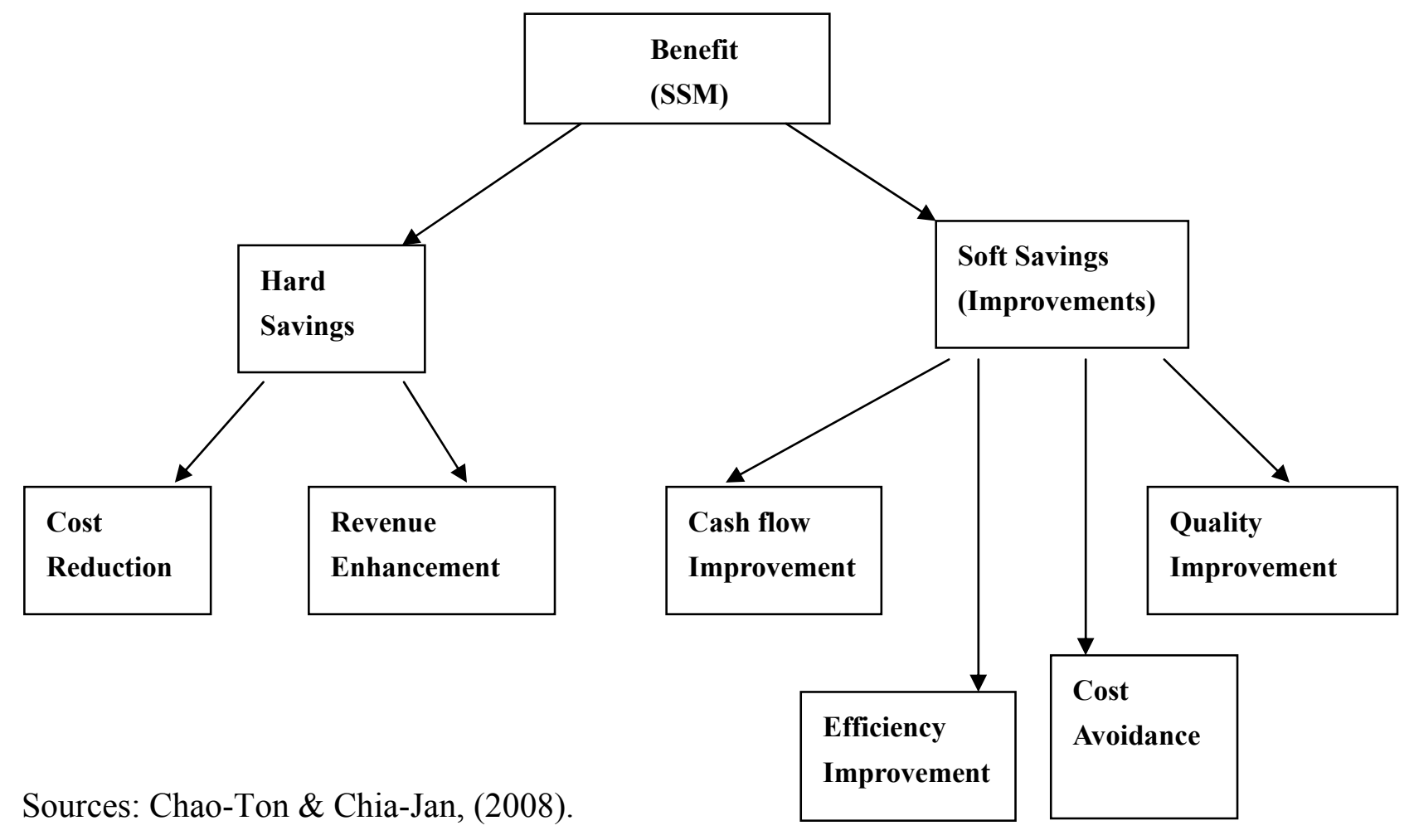

Figure 2. Benefit of Six Sigma methodologies

\section{Methodology}

The population for the study consisted of 914 SMPs (Firms with between 1 to 6 partners) representing $99.8 \%$ of the total firms licensed by the Institute of Chartered Accountants of Nigeria to provide auditing services. Only Principal partners of SMPs responsible for strategic decision making were selected as respondents due to their involvement in their firms' management. The Sample size of 137 consists of $15 \%$ of SMPs population which forms the basis 137 copies of questionnaire administered at random. 133 valid questionnaires were filled and returned. The questionnaire distribution was independent of sex and Age. The instrument consisted of a 9 - term survey questionnaire with a - 5 Likert scale response options. Strongly Agreed (SA), Agreed (A), Undecided (U) Disagree), and Strongly Disagreed (SD). Pilot survey was adopted for the reliability test and it yielded correlation coefficient of 0.84 . The questionnaire was structured in line with the objective, research questions and hypothesis of the study. Data was analyzed and Pearson Product Moment Correlation method was used to confirm the hypotheses of the study. The formulae are:

$$
\mathrm{r}=\mathrm{N} \Sigma \text {, by }-(\Sigma \mathrm{x})(\Sigma \mathrm{y}) / \sqrt{ } \mathrm{N} \Sigma \mathrm{x}^{2}-(\mathrm{x})^{2} \sqrt{ } \mathrm{N} \sqrt{ }^{2}-(\mathrm{y})^{2}
$$




\section{Macrothink}

\subsection{Test of Statistical Hypothesis}

\section{Hypothesis 1:}

$\mathbf{H}_{\mathbf{0}}$ : There is no significant relationship between TQM and SMP performance in Nigeria

$\mathbf{H}_{1}$ : There is significant relationship between TQM and SMP performance in Nigeria

Table 4. Calculation of Correlation

Question 2 of questionnaire administered: Adoption of TOM will positive influence SMPs performance in Nigeria

\begin{tabular}{|c|c|c|c|c|c|}
\hline Options & Point $(\mathbf{x})$ & Response (y) & $\mathbf{( x y )}$ & $\left.\mathbf{( x}^{\mathbf{2}}\right)$ & $\left(\mathbf{y}^{\mathbf{2}}\right)$ \\
\hline SA & 5 & 73 & 65 & 25 & 5,329 \\
\hline A & 4 & 32 & 128 & 16 & 1,024 \\
\hline U & 3 & 7 & 21 & 9 & 49 \\
\hline D & 2 & 8 & 16 & 4 & 64 \\
\hline SD & 1 & 13 & 13 & 1 & 169 \\
\hline $\mathbf{\Sigma}$ & $\mathbf{1 5}$ & $\mathbf{1 3 3}$ & $\mathbf{5 4 3}$ & $\mathbf{5 5}$ & $\mathbf{6 , 6 3 5}$ \\
\hline
\end{tabular}

Source: Author's Computation, September 2012

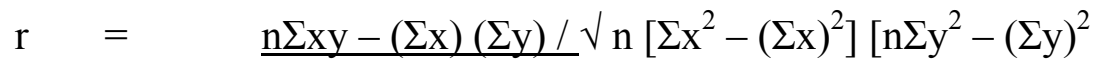

Where: $\mathrm{n}=5, \Sigma \mathrm{x}=15, \Sigma \mathrm{y}=133, \Sigma \mathrm{xy}=543, \Sigma \mathrm{x}^{2}=55, \Sigma \mathrm{y}^{2}=6,635$

$$
\begin{aligned}
\mathrm{r} & =5(543)-(15)(133) / \sqrt{ } 5\left[(15)-(15)^{2}\right]\left[5(6,635)-(133)^{2}\right] \\
& =2,715-1,995 / \sqrt{ }(275-225)(33,175-17,689) \\
& =\quad 720 / \sqrt{ }(50)(15,486)=720 \_880=0.818 \underline{\underline{\mathbf{r}=\mathbf{0 . 8 2}(\mathbf{8 2 \%})}}
\end{aligned}
$$

Decision: $r$ calculated of $0.82 \geq 0.5$ level of significance. The alternate hypothesis is accepted that says: There is significant relationship between TQM and performance of SMPs in Nigeria Therefore the null hypothesis is rejected

\section{Hypothesis 11:}

$\mathbf{H}_{\mathbf{0}}$ : Six Sigma Methodology has no significant influence on SMP services delivery in Nigeria.

$\mathbf{H}_{1}$ : Six Sigma Methodology has significant influence on SMP services delivery in Nigeria 
Table 5. Calculation of Correlation

Question 5 of questionnaire administered: Six Sigma Methodology has no significant influence on SMP services in Nigeria.

\begin{tabular}{|c|c|c|c|c|c|}
\hline Options & Point (x) & Response (y) & $\mathbf{( x y )}$ & $\left.\mathbf{( x}^{\mathbf{2}}\right)$ & $\left(\mathbf{y}^{\mathbf{2}}\right)$ \\
\hline SA & 5 & 50 & 250 & 25 & 2,025 \\
\hline A & 4 & 28 & 112 & 16 & 784 \\
\hline U & 3 & 9 & 27 & 9 & 81 \\
\hline D & 2 & 18 & 36 & 4 & 324 \\
\hline SD & 1 & 28 & 28 & 1 & 784 \\
\hline $\mathbf{\Sigma}$ & $\mathbf{1 5}$ & $\mathbf{1 3 3}$ & $\mathbf{4 5 3}$ & $\mathbf{5 5}$ & $\mathbf{4 , 4 7 3}$ \\
\hline
\end{tabular}

Source: Author's Computation, September 2012

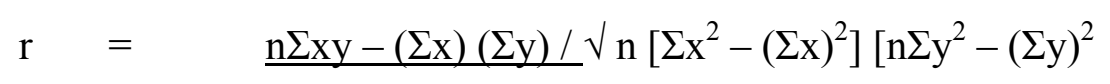

Where: $\mathrm{n}=5, \Sigma \mathrm{x}=15, \Sigma \mathrm{y}=133, \Sigma \mathrm{xy}=453, \Sigma \mathrm{x}^{2}=55, \Sigma \mathrm{y}^{2}=4,473$

$$
\begin{aligned}
\mathrm{r} & =5(453)-(15)(133) / \sqrt{ } 5\left[(15)-(15)^{2}\right]\left[5(4,473)-(133)^{2}\right] \\
& =2,165-1,995 / \sqrt{ }(275-225)(22,365-17,689) \\
& =\quad 170 / \sqrt{ }(50)(4,676) \quad=170 \_484=0.351 \quad \underline{\underline{\mathbf{r}=\mathbf{0 . 3 5 ( 3 5 \% )}}}
\end{aligned}
$$

Decision: $r$ calculated of $0.35 \leq 0.5$ level of significance. The null hypothesis is accepted that says: There is no significant relationship between TQM and performance of SMPs in Nigeria. Therefore the alternative hypothesis is rejected.

\section{Discussion of Result}

The article investigated relationship between TQM and SMPs performance on one hand and influence of SSM on SMP service rendition the other. The work attempted to fill a gap in TQM research with a survey of SMPS in Nigeria. Hypothesis 1 tested in table 4 revealed that there is significant relationship between TQM and SMPs performance. This issue was addressed by question 2: Adoption of TOM will positive influence SMPs performance in Nigeria with 55\% to rank first. The effect of TQM is seldom seen in SMP performance due to lack of resources to implement it. This notion was confirmed by question 1: SMP in Nigeria does not have enough resources to improve quality of service renders to clients. Hypothesis 2 tested in tables 5 revealed that Application of Six Sigma Methodology has not influenced SMP service rendition in Nigeria. This is due to ignorance on the part of SMPs Principal Partners. This issue was addressed by question 5 of the questionnaire with $34 \%$ to rank $4^{\text {th }}$. The " $r$ " calculated of 0.82 and 0.35 shows that there is strong positive correlation between TQM and SMPs performance but inconsequential application has led to no influence in quality services renders hence the benefit SSM is not fully tapped.

\section{Summary of Findings}

Based on the analysis carried out, the following findings were revealed (i) there is a significant but relationship between TQM and organizational performance. (ii) most SMPs principal 
partners are not conversant with the concept (iii) few SMPs train employees, provide leadership for continuous improvement in services and meets consumer's expectations (iii) SMPs staff embarks on self development with little salary package which affects personnel input in service engagement (iv) Quality service can only be provided if continuous improvement is achieved which is lacking in SMPs operations (v) SMPs are ignorant of the concept of Six sigma methodology hence could not apply it.

\section{Concluding Remarks and Recommendations}

TQM is a management approach which seeks to establish zero defects in any part of service provision in an organization. Current business system (CBS) coupled with Six Sigma Methodology (SSM) will result in TQM. However, due to ignorance, the concept is neither employed in part or in whole which makes it impossible for the SMP to harvest the benefit of TQM. This might be one of the reasons why SMPs in Nigeria are neither providing excellent services nor developing into full-size accountancy organizations. Instead some are winding up. The study recommends that SMP should embrace SSM to have significant clients' relationship, improved performance and maximize institutional prosperity.

\section{Acknowledgement}

The authors wish to thank the Editor and Reviewers of this journal for their helpful comments and suggestions on draft of the article. Also Dr. Umukoro of Babcock University for his mentorship and Professors Enyi Patrick Enyi my Ph.D. supervisor.

\section{References}

Ayagari, M. T. B., \& Demirguc-kunt, A. (2003). Small and Medium Enterprises across the Globe. A New database. World Bank, Development Research Group. Working paper 3127 Washington DC Baoden

Ariyo, D. (1999). Small firm are the Backbone of Nigeria economy. Africa Economic Analysis, Africa Business Information Service, Bridgnorth United Kingdom.

Bilich, F., \& Neto, A. A. (2000). Total quality management: quality macro-function model for banks. Total Quality Management, 11(1), 5-15. http://dx.doi.org/10.1080/0954412006982

Chang, S. C., Lin, N. P., Yang, C.-L., \& Sheu, C. (2003). Quality dimensions, capabilities and business strategy: An empirical study in high-tech industry. Total Quality Management, 14(4), 407-421. http://dx.doi.org/10.1080/1478336032000047228

Chao-Ton, S., \& Chia-Jan, C. (2008). A Systematic Methodology for the Creation of Six Sigma Projects: A Case Study of Semi-conductor Foundry. Expect System with Application, 34, 2693-2703. http://dx.doi.org/10.1016/j.eswa.2007.05.014

Costin, H. (1994). Total Quality Management. United States of America publications.

Cua, K. O., McKone, K. E., \& Schroeder, R. G. (2001). Relationships between implementation of TQM, JIT, and TPM and manufacturing performance. Journal of Operations Management, 19(6), 675-694. http://dx.doi.org/10.1016/S0272-6963(01)00066-3 
Dale, B.G. (2003). Managing Quality, Fourth Edition, Hertfordshire: Prentice Hall.

Demirbag, M., Tatoglu, E., Tekinkus, M., \& Zain, S. (2006). An analysis of the relationship between TQM implementation and Organizational Performance. Journal of Manufacturing Technology Management, 17.

Evans, J.R., \& Dean, J.W. (2003). Total quality: Management, organization and strategy (3rd ed.). Mason: Thompson South-Western.

Ekpeyong, D., \& Nyang, M.O. (1992). Small and Medium Scale Enterprises in Nigeria: Their Characteristics, Problems and Sources of Finance. African Economic Research Consortium, Nairobi.

Eriksson, H., \& Hansson, J. (2003). 'The impact of TQM on financial performance. Measuring Business Excellence, 7(1), 36-50. http://dx.doi.org/10.1108/13683040310466717

Gross, J. M., \& McInnis, K. R. (2003). Kanban Made Simple - Demystifying and Applying Toyota's Legendary Manufacturing Process. American Management Association, New York.

Hansson, J. (2003). Total quality management. Aspects of implementation and performance. Investigations with a focus on small organizations", doctoral thesis, Division of Quality \& Environmental Management, Lulea University of Technology, Lulea.

Hoyer, R.W., \& Hoyer, B. K.Y. (2001). Implementation of Total Quality Management in Small Organizations: A Case Study in Sweden. Total Quality Management, 12(7\&8), 988-994.

ICAN. (2011). List of Audit Practice firms in Nigeria. Institute of Chartered Accountants of Nigeria. Membership department Record.

IFAC. (2010). The Role of Small and Medium Practices in Providing Business Support to Small- and Medium- sized Enterprises, Small and Medium Practices Committee Information Paper $\mathrm{p} 10$.

Jamal, A., \& Naser, K. (2002). Customer satisfaction and retail banking: An assessment of some of the key antecedents of customer satisfaction in retail banking. International Journal of Bank Marketing, 20(4/5), 146-161. http://dx.doi.org/10.1108/02652320210432936

Levesque, T., \& McDougall, G.H.G. (1996). Determining of customer satisfaction in retail banking, International Journal of Bank Marketing, 14(7), 12-20. http://dx.doi.org/10.1108/02652329610151340

Lucey, T. (2002). Quantitative Techniques, (6 ${ }^{\text {th }}$ edition); Tottenham Court London; Book Power, United Kingdom.

Mani, K. E., Putterill, M. S., \& Sluti, D. G. (1994). Empirical analysis of quality Improvement in manufacturing. International Journal of Quality \& Reliability Management, 11(7), 19-37. http://dx.doi.org/10.1108/02656719410738984 
Nwabueze, U. (2001). An industry betrayed: the case of total quality management in manufacturing, The TQM Magazine, 13(6), 400-408. http://dx.doi.org/10.1108/EUM0000000006177

Oakland, J. (2000). Total Quality Management (2ed.). Oxford, Great Britain: Butterworth-Heinemann.

Okpala, K.E. (2012a). Fiscal Accountability Dilemma in Nigeria Public Sector: A warning Model for Economic Retrogression. Journal of Finance and Accounting, 3(6), 113-131

Okwuadigbo, N. A. (2012, August 16). The Role of IFAC in the Survival and Growth of SMPs. Paper presented at the Forum of Firms of the Institute of Chartered Accountants of Nigeria (ICAN). Lagos.

Pycraft, M., Singh, H., \& Phihlela, K. (2000). Operations Management. Pretoria. Pearson Education.

Rouse, M. (2005). Definition of total quality management, Related glossary terms. Updated September.

Schonberger, R. J., \& Knod, E.M. (1997). Operations management: Customers Focused Principles. Boston: Irwin.

Schonberger, R. J. (1990). Building a Chain of Customers: Linking Business Function to Create a World - Class Company. New York: The Free Press.

Schroeder, R. A. (2006). Six Sigma: The Breakthrough Management Strategy Revolutionizing the World's Top Corporations. Sydney: Currency. 9. ISBN 0-385-49438-6.

Snee, R.D. (2004). Six Sigma: the evolution of 100 years of business improvement methodology. International Journal of Six Sigma and Competitive Advantage, 1(1), 4-20. http://dx.doi.org/10.1504/IJSSCA.2004.005274

Surya, R.U., Pal Pandi, A., \& Jeyathilagar .D, (2007). An Analytical Study of Integrated Total Quality Management practices in Technical Education. Faculty Perspective, Proceedings of the 9th International Symposium on Measurement and Quality Control, IIT Madras, India, 375-379.

Tennant, G (2001). Six Sigma: SPC and TQM in Manufacturing and Services. Gower Publishing, Ltd, 6. ISBN $0-566-08374-4$. http://books.google.com/?id=O6276jidG3IC\&printsec=frontcover\#PPA6,M1.

Vroman, H.W., \& Luchsinger, V.P. (1994). Managing Organization Quality: Illinois: Irwin, Inc.

Wilkinson, A. Marchington, M., Goodman, J., \& Ackers, P. (1992). Total Quality Management and Employee Involvement. Human Resource Management Journal, 2(4), 1-20. http://dx.doi.org/10.1111/j.1748-8583.1992.tb00263.x 


\section{Macrothink}

Asian Journal of Finance \& Accounting ISSN 1946-052X 2012, Vol. 4, No. 2

Wiklund, H., \& Wiklund, S. (2002). Widening the Six Sigma concept: an approach to improve organizational learning. Total Quality Management, 13, 233-239. http://dx.doi.org/10.1080/09544120120102469

Wyper, B., \& Harrison, A. (2000). Deployment of Six Sigma Methodology on Human Resources Function: A Case Study. Total Quality Management, 11(495), 720-727. http://dx.doi.org/10.1080/09544120050008129

Yong, J., \& Wilkinson, A. (2001). Rethinking total quality management. Total Qual. Manage., 12, 247-258. http://dx.doi.org/10.1080/09544120120011460

Zeithaml, V.A., \& Bitner, M. J. (1996) Services Marketing, (1st ed). McGraw-Hill, New York.

Zenith Economic Quarterly. (2010). Implementation of Total Quality Management. 


\section{I Macrothink}

\section{Appendix 1}

Table 3. Distribution and return of questionnaire

\begin{tabular}{|l|l|c|c|c|c|c|}
\hline No & Question & $\begin{array}{c}\text { Sample } \\
\text { size }\end{array}$ & $\begin{array}{c}\text { Respons } \\
\text { e }\end{array}$ & $\begin{array}{c}\text { Responden } \\
\text { ts }\end{array}$ & $\begin{array}{c}\text { Percenta } \\
\text { ge }\end{array}$ & Ranking \\
\hline 1 & SMP in Nigeria does not have & 133 & SA & 61 & $46 \%$ & \\
& enough resources to improve & & A & 23 & $17 \%$ & \\
& quality of service renders to & & U & 5 & $4 \%$ & 2 nd \\
& clients. & & D & 24 & $18 \%$ & \\
\hline 2 & Adoption of TOM will positive & 133 & SA & 20 & $15 \%$ & \\
& influence SMPs performance & & A & 32 & $24 \%$ & \\
& in Nigeria & & U & 7 & $5 \%$ & 1 st \\
& & & D & 8 & $6 \%$ & \\
& & & SD & 13 & $10 \%$ & \\
\hline 3 & Management of SMPs does not & 133 & SA & 50 & $38 \%$ & \\
& embrace quality controls in their & & A & 30 & $23 \%$ & \\
& operations. & & U & 6 & $5 \%$ & 3 rd \\
& & & D & 28 & $21 \%$ & \\
& & & SD & 19 & $14 \%$ & \\
\hline 4 & Six Sigma Methodology are & 133 & SA & 23 & $17 \%$ & \\
& employed by SMPs in Nigeria to & & A & 14 & $11 \%$ & \\
& achieve total quality & U & 9 & $7 \%$ & 5 th \\
& management in their service & & D & 32 & $24 \%$ & \\
& renditions & & SD & 55 & $41 \%$ & \\
\hline 5 & Application of Six Sigma & 133 & SA & 45 & $34 \%$ & \\
& Methodology has influence on & & A & 28 & $21 \%$ & \\
& SMP service rendition in & & U & 9 & $7 \%$ & 4 th \\
& Nigeria & & 18 & $14 \%$ & \\
& & & 33 & $25 \%$ & \\
\hline
\end{tabular}

Source: Field survey, September 2012 